\title{
Sedimentation Study of Sandstone Turbidite Sequence of Cinambo Formation in Maja Area, Majalengka, West Jawa - Indonesia
}

\author{
Yan Rizal ${ }^{1, \text { * }, \text { Wahyu Dwijo Santoso }}{ }^{1}$, Sapta Djanuismawan ${ }^{1}$, Alfend Rudyawan ${ }^{1}$, \\ Affan Arif Nurfarhan ${ }^{2}$ \\ ${ }^{1}$ Geology Department, Institute of Technology Bandung, Bandung, Indonesia \\ ${ }^{2}$ Geology Department, Sekolah Tinggi Teknologi Mineral Indonesia, Bandung, Indonesia
}

\section{Email address:}

yan@gl.itb.ac.id (Y.Rizal), geawahyu08@gmail.com (W. D. Santoso), sapta.l.djanuismawan@gmail.com (S. Djanuismawan), alfend@gl.itb.ac.id (A. Rudyawan), a.a.nurfahan@gmail.com (A. A. Nurfarhan)

${ }^{*}$ Corresponding author

\section{To cite this article:}

Yan Rizal, Wahyu Dwijo Santoso, Sapta Djanuismawan, Alfend Rudyawan, Affan Arif Nurfarhan. Sedimentation Study of Sandstone Turbidite Sequence of Cinambo Formation in Maja Area, Majalengka, West Jawa - Indonesia. Earth Sciences.

Vol. 8, No. 3, 2019, pp. 190-204. doi: 10.11648/j.earth.20190803.17

Received: May 21, 2019; Accepted: June 27, 2019; Published: July 10, 2019

\begin{abstract}
Administratively the study area is located in Maja Village which situated near the border of between Sumedang and Majalengka Regency, West Jawa - Indonesia. Geographically located at coordinates 108 $111^{\prime} 28^{\prime \prime}-108^{\circ} 13^{\prime} 42^{\prime \prime}$ Longitude and $6^{\circ} 51^{\prime} 28^{\prime \prime}-6^{\circ} 55^{\prime} 30^{\prime}$ Lattitude. In the study area the Formation Cinambo was widely distributed. Geological observation was conducted in Cirompoki River, Kadu River, and Cimaningtim River such as outcrops description and detail measuring section and rock sampling for granulometry as well as biostratigraphy analysis. The stratigraphy of Cinambo Formation is divided into Claystone-sandstone unit (facies D), Sandstone-mudstone units (facies C), Sandstone Unit (facies B) and Claystone units (facies E). This formation deposited in the mechanism of high density turbidite current. Plankton fossils showed that this formation was deposited in Middle Miocene to Early Pliocene (N11-N18) in upper bathyal environment. Integrated result of sediment profiles and granulometry showed that sedimentation of Cinambo Formation had characteristics which are: coarsening upward, etc. The vertical succession of Fm. Cinambo sandstone caused by current mechanisms of saltation, suspension, traction, that changed according to depositional environment. This formation was deposited in the outer part of submarine fan change until its middle part. Environmental change caused by influenced of eustacy in relative sea level drop.
\end{abstract}

Keywords: Turbidite, Fm. Cinambo, Granulometry, Eustacy

\section{Introduction}

Turbidite deposits was the sedimentation formed as a result of gravity currents in the slope area, formed both in a sudden or continuous event, and may occur in short or long time due to energy involved, wether it may be earthquakes, floods or falling sediments. In the petroleum industry, many studies on turbidite sediments began to develop either surface data or seismic data, because turbidite deposits play an important role as potential reservoirs in several oil fields in Indonesia.

The Cinambo formation formed in Bogor Basin during the middle to late Miocene, which known as turbidite deposit in deep sea fan environment [1]. Research sites are located in Maja Village on the border of Sumedang and Majalengka, West Java (108 $11^{\prime} 28^{\prime \prime}$ - 108 $13^{\prime} 42^{\prime \prime}$ Longitude and 651'28" - 655'30" Lattitude (Figures 1,2). The site was selected, because the adequate presence of ideal rock outcrops with excellent and fresh condition, which can show a good record of turbidite depositional system. Also, to provide good geological data for the inundation process of Jatigede Dam Area.

This study emphasizes the analytical characteristics of grain sandstone lithology to interpret the sedimentation mechanism of turbidite sedimentation, by analytical 
approaches through grainsize analysis based on granulometric test to identify the settlement mechanism of the Cinambo Formation, interpreting the settling environment and estimating the geological events that affect the sedimentation of the Cinambo Formation.

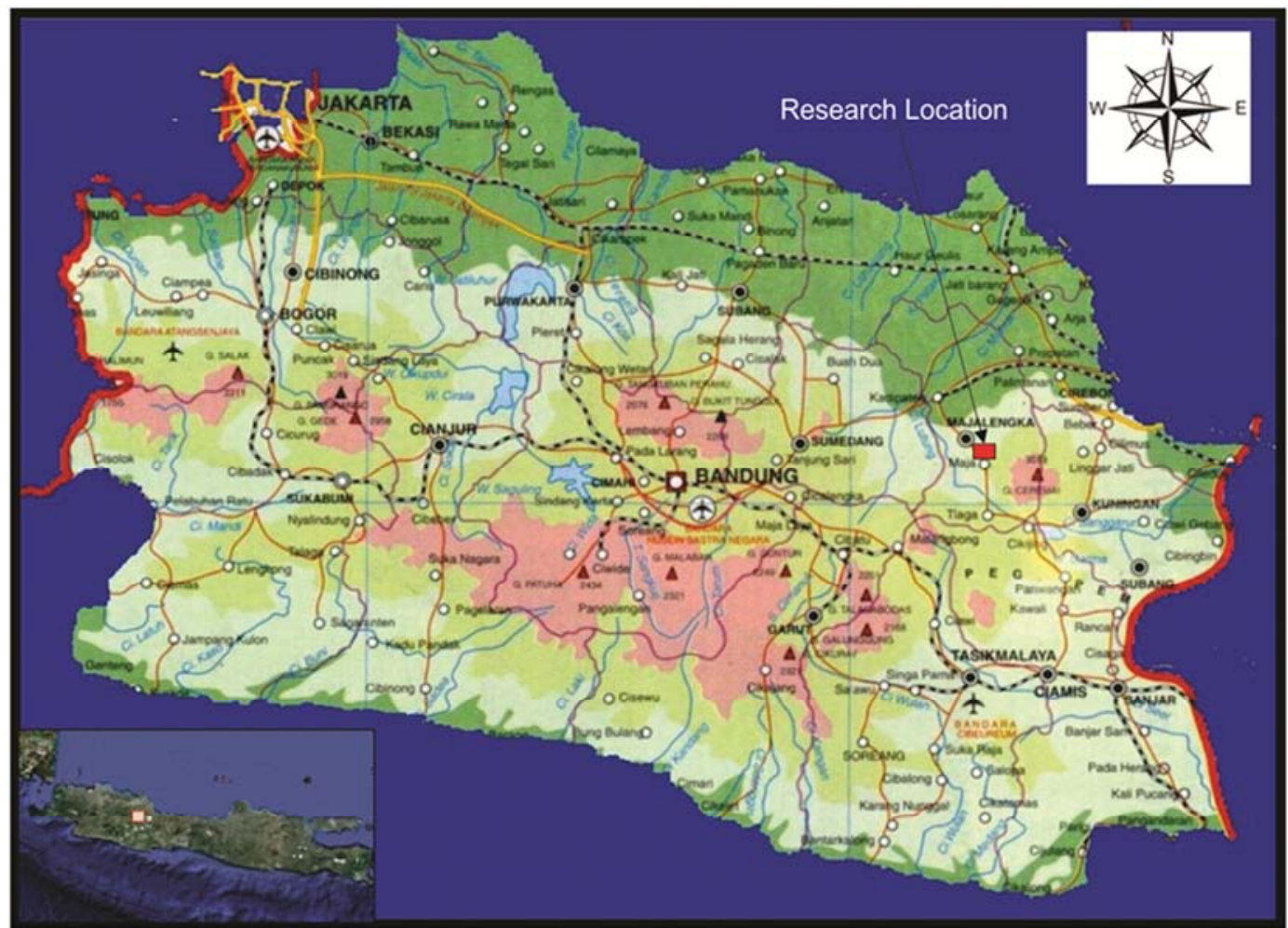

Figure 1. Research Location map.

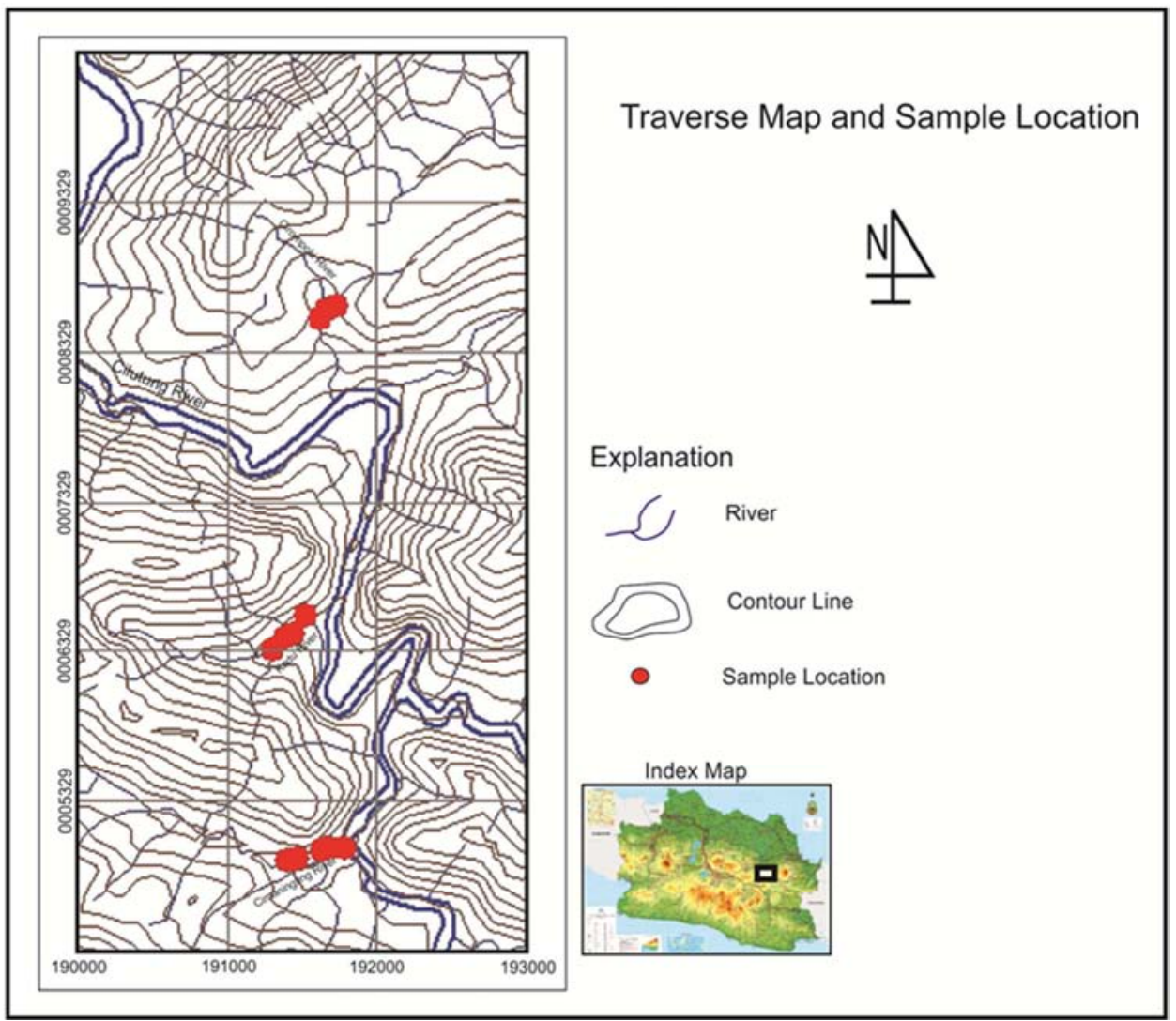

Figure 2. Traverse Map and sample Location. 


\subsection{Regional Stratigraphy}

Regional Stratigraphy provides an overview description of specific formations that are closely related to the stratigraphy units of the study area from the oldest to the youngest one, in chronological order.

In the Geological Map Sheet Arjawinangun [2] mentions the oldest to the youngest rocks as follows: Oligo-Miocene Cinambo Formation, Kromong Kombong Limestone in early Miocene, Middle-aged Halang Formation Miocene, Subang Formation Middle to late Miocene, Kaliwangu Formation early-age Pliocene, Citalang Formation middle to late Pliocene, Quaternary-aged Folded Breccia, Old Mountained Volcano, Young Quaternary Youth Results, and RecentOwned Aluvium.

\subsection{Cinambo Formation}

According to geological maps of the Arjawinangun Sheet Area [2], in general the Cinambo Formation is divided into two units namely: Sandstone Member (lower part) and Shale Member (upper part). Sandstone members consist of graywacke, which features thick bedded with shalke intercalation, thin layered claystone, calcareous sandstone, tuff, claystone, and siltstone. The Shale member consists of a claystone with sandstone intercalation, limestones, calcareous sandstone and tuffaceous sandstone. This formation is a gravity flow deposit, which deposited in deep marine fan environments at N12 to N18.

The lower Cinambo formation consist of Cyclics alternation of siltstone and claystone, which begins with a green claystone exposed north of Jatigede, on the Cisaar Landeuh River. Claystone contains many planktonic foram fossils. This unit also encountered siltstone and fine sandstone as thick as $5-30 \mathrm{~cm}$. Sandstone is generally laminated and calcareous. Then on top of it was found alternation of siltstone and claystone. These loop cycle cycles have the perfect thickness or rock type to form the typical "flysch" sequence and each layer has a thickness of 20-25 $\mathrm{cm}$. Some sandstone intercalation has a thickness reach up to $65 \mathrm{~cm}$, often show a complete series of Bouma sequence [3] of $\mathrm{Ta}, \mathrm{Tb}, \mathrm{Tc}, \mathrm{Td}, \mathrm{Te}$. It is also often found ichno fossil printed on lower part of the sandstone. The composition of sandstone consists of feldspar, quartz, igneous rock fragments and clay minerals, and poor sorting [5]. This series covered by calcareous sandstone unit containing fragments of bentic foraminiferas fossil (Spiroclypeus and Lepidocyclina) and has a thickness of $50-150 \mathrm{~cm}$. Also found there, conglomeratic sandstone with fragments of clay component, and $50-150 \mathrm{~cm}$ thick. The the claystone unit of lower Cinambo formation is containing many plankton fossils, including Globorotalia lobata and globorotalia peripheronda showing the age of N11 [1].

The upper unit of the Cinambo Formation consists of sandstones with claystone intercalation. Sandstones generally built up by fine grained to coarse sand, with a sedimentary structure in the form of layers and parallel laminate in layer of $5-250 \mathrm{~cm}$. The sandstones and claystone units contain Globorotalia mayeri and Globorotalia menardii fossils which show the age of N12-N13 [6]. Sandstone contains fossil of foraminifera planktonic such as Spiroclypeus orbitoides, Myogypsina thecideformis, Miogypsina dehartii, Cycloclypeus sp., and Lepidocyclina sumatrensis. In the claystone intercalation found planktonic foraminifera of Globorotalia linguaensis, Globorotalia menardii, and Globorotalia mayeri of N13 ages [7]. Furthermore, fossils of age of N15 to N18 was found at the upper most part of the Cinambo Formation. The loss of the settling age between the lower and upper portions of N14 is estimated as the time of deposition of the breccia unit.

Upper Cinambo Formation which known as Jatigede member has a thickness of about $275 \mathrm{~m}$. This lithologic unit consists of alternating breccias and sandstones and occasionally with claystone. Breccia is gray with a matrix of sand, and igneous rock fragments of the andesite pyroxene type. Fragments are angled at $20 \mathrm{~cm}$, and in some layers found graded bedding structure. This breccia covered by claystone with $5-20 \mathrm{~cm}$ siltstone and sandstone intercalation. Claystone, dark gray, conchoids, contains planktonic fossils. The more upward sandstone became more dominant. Sandstone has brownish gray color, medium to coarse grain size. In some layers found graded bedding sedimentary structure.

\section{Methodology}

This research was conducted in 3 stages, namely the phase of field data collection, laboratory and studio stage. Field data collection includes observation and description of outcrop, detail measuring section and sampling that can represent vertical sediment distribution. While the stages of the laboratory in the form of sample analysis for the analysis of granulometry and paleontology (biostratigraphy) to be able to see the character of the grain and fossil content. Microfossil analysis uses Blow classification [6] for determining age, while Robertson classification (1985) used in determining the depth of the environment. The studio stage performs analysis and interpretation of measuring section data, granulometry and paleontology so as to provide an overview of the sedimentation history of Cinambo Formation to be depicted in the sedimentary environment model.

\section{Result}

\subsection{Stratigraphy Study Area}

The lithology of study area is dominated by clastic sedimentary rocks such as sandstones, claystone, and silt rock. The grouping of the clastic sedimentary rocks based on similarity of lithologic features such as thickness, texture and sedimentary structure and arranged in chronological order by its planktonic fossils content.

The lithology unit of the study area is divided into 4 (four) 
units (from old to young), ie, the Claystone-Sandstone Unit, the Sandstone-Claystone Unit, the Sandstone Unit and the Clayastone Unit.

\subsubsection{Claystone - Sandstone Unit}

Claystone - Sandstone Unit is located in the northern part of the study area, precisely in Cirompoki River (Figure 3). In this river (ca. $40 \mathrm{~m}$ long tracking) there is a claystone is predominantly inserted with sandstone. Claystone, dark gray color, slightly greenish, conchoidal fractured, non calcareous and 100-200 cm thick. At the middle part of this unit consist of alternation of Claystone and fine to medium grained sandstones, light gray color, medium sorting, has a sedimentary structure of Bouma [3] Tabc sequence with 5-10 $\mathrm{cm}$ thick and Tab with $30 \mathrm{~cm}$ thick and flute cast structure at bottom of sandstone. The lower part of this unit built by sandstone, brown color, medium to coarse grain, poor sorting, Tab structure, thickness up to $30 \mathrm{~cm}$, fining upwards.



Figure 3. Outcrops of Claystone-Sandstone Units in Cirompoki River.

\subsubsection{Sandstone - Claystone Unit}

This unit is exposed on the Kadu River in the center of the study area (Figure 4). In this river (ca. $65 \mathrm{~m}$ track measurement) was found an outcrop of alternating thin layered sandstone and claystone. The Sandstones are fine to coarse grain, light gray, moderate to poor sort, some of them are calcareous, $20-50 \mathrm{~cm}$ thick. Load cast sedimentary structure at the bottom of the layer, coarsening and thickening upwards and the Tab and Tabc Bouma sequences [3]. The clay is dark gray, slightly greenish, non calcareous and $20-50 \mathrm{~cm}$ thick.



Figure 4. Outcrops of Sandstone - Claystone Unit in Kadu River. 


\subsubsection{Sandstone Unit and Claystone Unit}

These units are found in Cimaningtim River located in the southern part of the study area, and it is a unit that exposed downstream of the river that joint into the Ciluntung River (Figure 5).

\section{i Sandstone Unit}

This unit consists of alternating of sandstone and thin layered clay. Total thickness of this unit is about 80 meters. Sandstone is light gray, fine to coarse sand, moderate to poor sorted, compact, containing also claystone fragments and thicknes varied from $20 \mathrm{~cm}$ to $350 \mathrm{~cm}$, with a feature of thickened and coarsened upwards and erotional contact to the sediment layer below it, with sedimentary structure in the form of load cast, flute cast, and groove cast. In finer fraction of sandstone found traces fossil. This sandstone has an interval Ta, Tbc, and Tabc, Tacd, Tae of Bouma sequence [3]. Thin layered Claystone has dark gray color, slightly fissile and is $5-10 \mathrm{~cm}$ thick.

ii Claystone units

This unit lay directly above Sandstone Units. The thickness of this unit is about 30 meter consist of mostly claystone with sandstone and siltstone intercalation. Claystone is dark gray color, slightly greenish, non calcareous with $100-150 \mathrm{~cm}$ thick. Sandstone are fine to medium grain, medium sorting, thickness varied from 5-10 $\mathrm{cm}$, containing trace fossils and a Tab and Tbc Bouma sequence [3]. Vertically the sandstones thinned and fined upward.



Figure 5. Outcrops of Sandstone - Claystone Unit in Kadu River.

\subsection{Lithofacies}

The lithology units are classified into lithofacies models [8] which modified from the Lithofacies classification model of Mutti and Ricci Lucchi [9] (Figure 6), based on the features and the appearance of rocks. The lithofacies units of the study area are: i Claystone - Sandstone Unit is class of siltstone and siltstone - claystone with D3 and D4 facies

ii Sandstone - Claystone Unit is class of sandstone claystone with $\mathrm{C} 3$ facies.

iii Sandstone Unit is class of sandstone with B3 and B4 facies.

iv Claystone Unit is a class of claystone with E4 facies. 


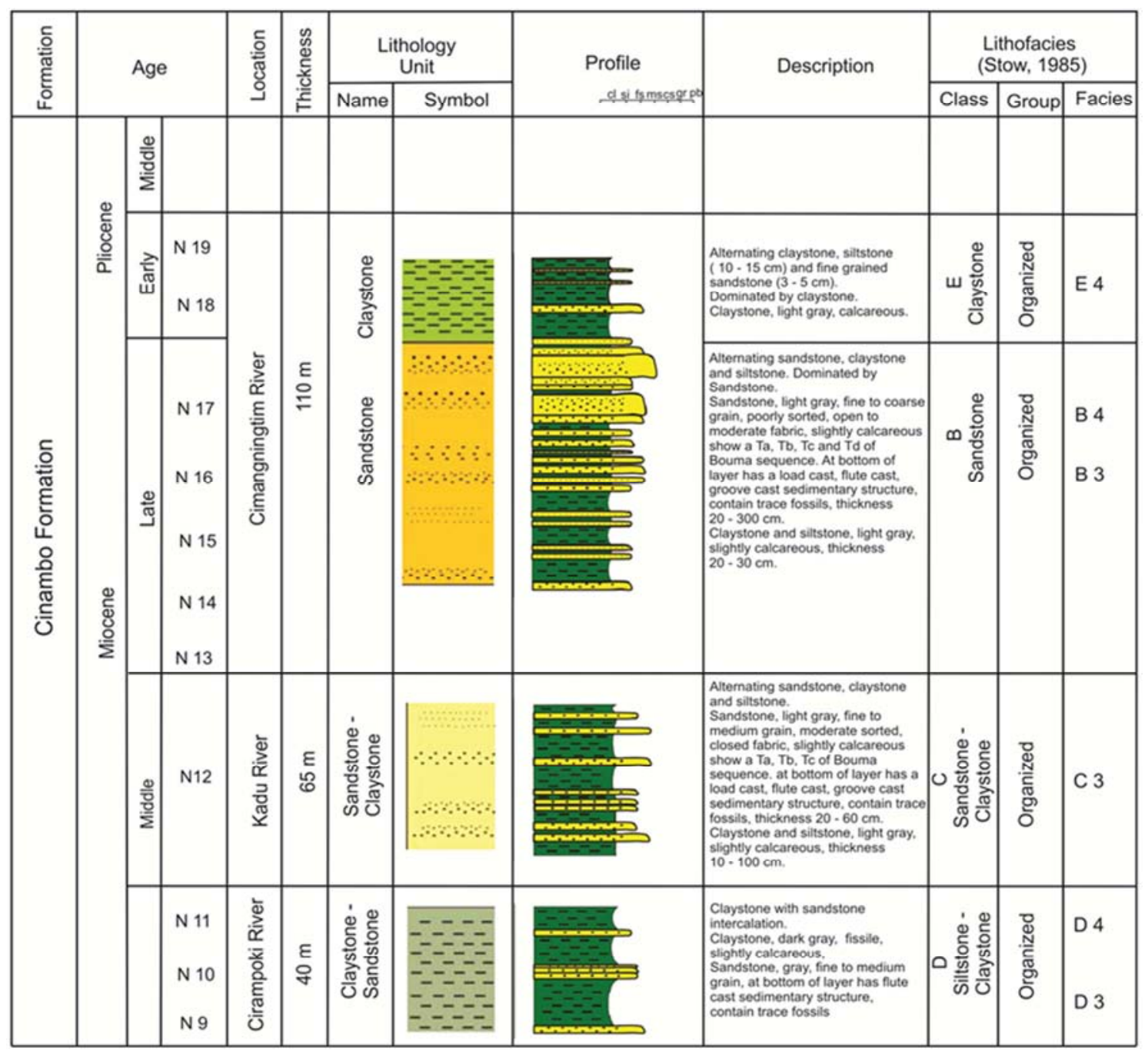

Figure 6. Stratigraphy and Lithofacies of Cinambo Formation.

\subsection{Deposition Environmental Association}

The determination of lithophasies is closely related to the determination of the deposition environment association. The presence of certain facies may indicate the conditions in the sedimentary environment. Based on the division of lithologic units and rock facies, it concluded that the model of the deposition environment association of the Cinambo Formation is:

i Claystone - Sandstone Unit (Siltstone - Claystone class of Facies D) and the Sandstone-Claystone Unit (Sandstone - Claystone class facies C) are in association of outer fan of deep marine fan environmental.

ii Sandstone unit (Sandstone class facies B) and Claystone unit of (Claystone class facies E) are in association of middle fan environmental.

\subsection{Biostratigraphy (Age) of Cinambo Formation in Research Area}

Based on the plankton fossil content that found in sample from Cirompok River, Kadu River and Cimaningtim River traverses, the rock age ordering from old to young can be arranged. The oldest unit in the study area came from rock unit from Cirompok River that shown by here is a Globorotalia foshi lobata fossil which is an index fossil for the Middle Miocene (N11-N12). Then followed by rock unit from Kadu River that show by Globorotalia foshi lobata and Globorotalia foshi robusta fossils which indicate a shorter deposition time in N12. The Youngest one is rock units from Cimaningtim River which show by presence of Globorotalia acostaensis, Sphaerodinellopsis seminulina and Globorotalia plesiotumida fossils that live from N15-N18 (Late Miocene to Early Pliocene) (Table 1).

The benthic fossils found in the outcrops of all three rivers (Table 2). From Cirompok River found Textularia sp., Nonion sp. (Inner to outer neritic) and Gyroidina sp. (upper bathyal). The fossils from Kadu River were Elphidium sp. (litoral), Nonion sp., Oolina sp., Robulus sp., Cassidulina sp., Lenticulina sp. (inner to outer neritic), and Uvigerina sp. (upper bathyal). And from Cimaningtim River found fossils of Oolina sp., Robulus sp., Bolivina sp., and Lagena sp. (middle to outer neritic).

The benthic of all three locations showed a mixture fossil 
which came from different environment. For environment interpretation, the fossil that came from the deeper environmental is used as indicator fossil for depositional environment, while fossil which came from the shallower environmental is interpreted as transported fossil to the deeper environment. So it can be interpreted that the depositional environment of the rock unit in Cimaningtim
River is outer neritic and upper bathyal for rock unit in Kadu River and Cirompoki River.

Based on the succession of the layering, it was interpreted that the sedimentation environment of the rock units found in the Cirompoki River was deeper than the rock units in the river kadu. It is generally seen as a decrease of sea level during the deposition of rock units of Cinambo Formation.

Table 1. Plantonic Fossil content of the study area.

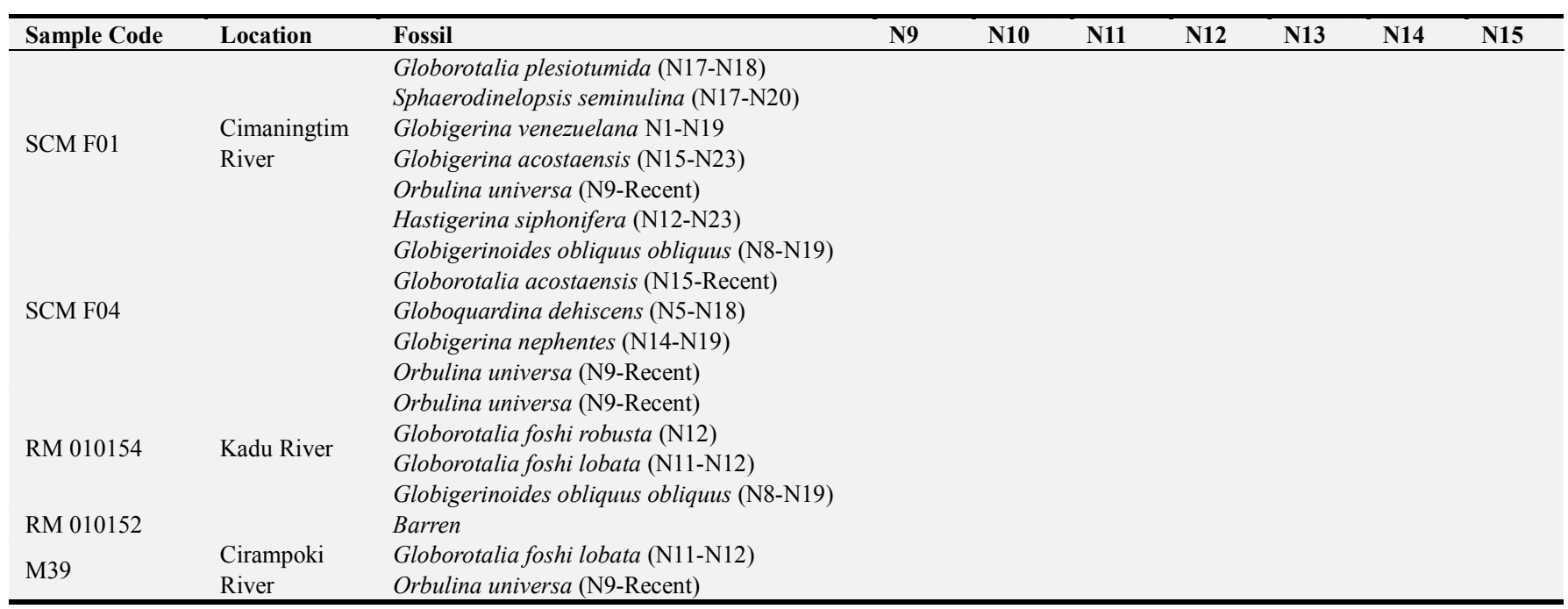

Table 1. Continued.

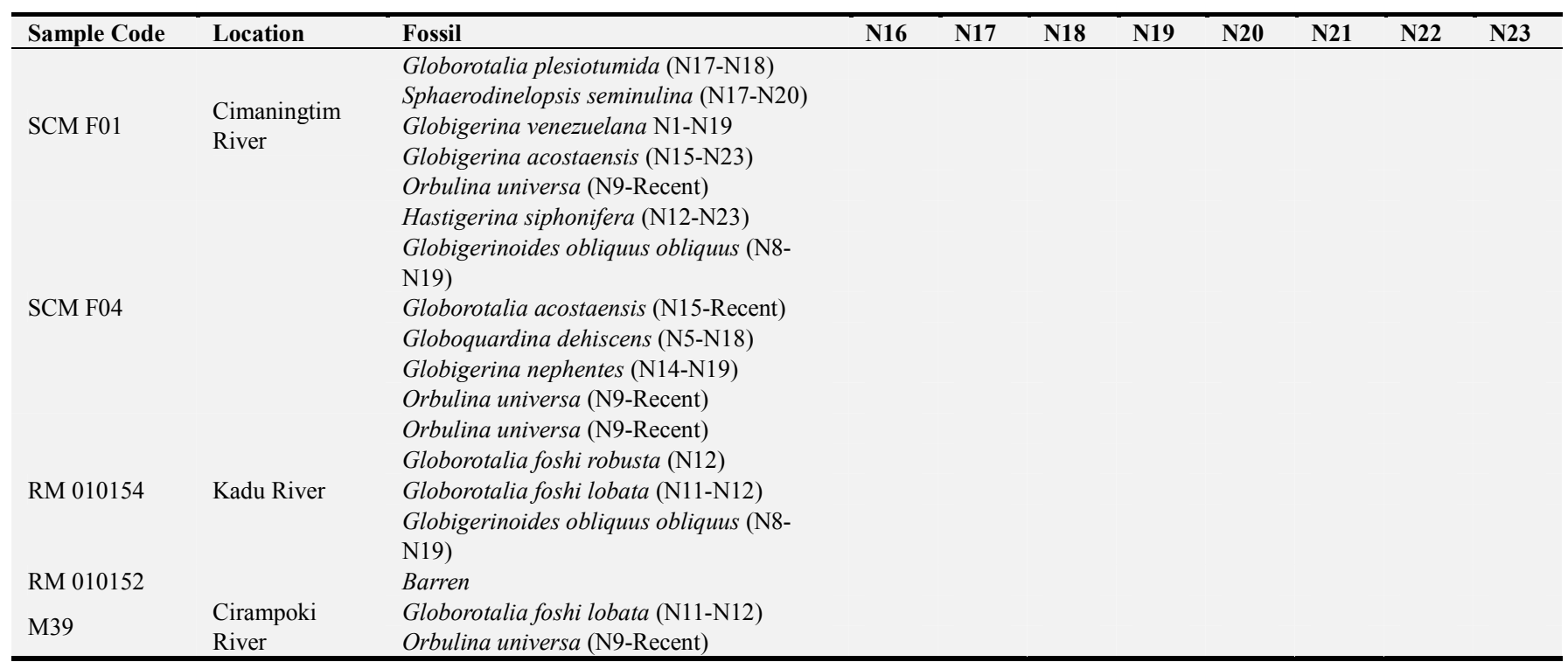

Table 2. Benthic fossil content of the study area.

\begin{tabular}{|c|c|c|c|c|c|c|c|}
\hline Sample Code & Foraminifera benthic & Littoral & Inner neritic & Middle neritic & Outer neritic & Upper bathyal & Lower Bathyal \\
\hline \multirow{4}{*}{ SCM F01 } & Lagena $\mathrm{sp}$ & & & & & & \\
\hline & Oolina $\mathrm{sp}$ & & & & & & \\
\hline & Bolivina $\mathrm{sp}$ & & & & & & \\
\hline & Robulus sp & & & & & & \\
\hline SCM F04 & Barren & & & & & & \\
\hline \multirow{4}{*}{ RM0101S4 } & Uvigerina $\mathrm{sp}$ & & & & & & \\
\hline & Oolina $\mathrm{sp}$ & & & & & & \\
\hline & Lenticulina $\mathrm{sp}$ & & & & & & \\
\hline & Robulus sp & & & & & & \\
\hline
\end{tabular}




\begin{tabular}{|c|c|c|c|c|c|c|c|}
\hline Sample Code & Foraminifera benthic & Littoral & Inner neritic & Middle neritic & Outer neritic & Upper bathyal & Lower Bathyal \\
\hline \multirow{4}{*}{ RM0201S2 } & Nonion sp & & & & & & \\
\hline & Cassidulina $\mathrm{sp}$ & & & & & & \\
\hline & Elphidinium $\mathrm{sp}$ & & & & & & \\
\hline & Textularia $\mathrm{sp}$ & & & & & & \\
\hline \multirow[t]{2}{*}{ M 39} & Gyroidina $\mathrm{sp}$ & & & & & & \\
\hline & Nonion $\mathrm{sp}$ & & & & & & \\
\hline
\end{tabular}

\subsection{Grainsize Analysis}

Rock groups for granulometric analysis were divided based on sampling location and lithology unit division. The rock group is divided into: Claystone sandstone Unit in Cirompoki River, Sandstone claystone unit in Kadu River and Sandstone and claystone units in Cimaningtim River. The Claystone sandstone unit in the Cirompoki River has an average grainsize of fine sand, with a very poor sorting. The sandstone-claystone unit in the Kadu River has an average grainsize of medium sand, with a poor sorting. The Sandstone Units and the Claystone Units in Cimaningtim River have an average grainsize of medium to coarse grain with very poor sorting. More detailed data are described in Table 3 below.

Table 3. Mean, median, mode and sortation of the samples.

\begin{tabular}{|c|c|c|c|c|c|}
\hline No & Sampel Code & Mean & Median & Mode & Sortation \\
\hline 1 & G01 & $30 / 0,75 / \mathrm{cs}$ & $30 / 0,75 / \mathrm{cs}$ & $40 / 1,25 / \mathrm{ms}$ & poor \\
\hline 2 & G09 & $50 / 1,75 / \mathrm{ms}$ & $50 / 1,75 / \mathrm{ms}$ & $20 / 0,25 / \mathrm{cs}$ & very poor \\
\hline 3 & G11 & $50 / 1,75 / \mathrm{ms}$ & $50 / 1,75 / \mathrm{ms}$ & $20 / 0,25 / \mathrm{cs}$ & very poor \\
\hline 4 & G17 & $50 / 1,75 / \mathrm{ms}$ & $70 / 2,25 / \mathrm{fs}$ & $20 / 0,25 / \mathrm{cs}$ & very poor \\
\hline 5 & G18 & $30 / 0,75 / \mathrm{cs}$ & $20 / 0,25 / \mathrm{cs}$ & $16 /-0,25 \mathrm{vcs}$ & poor \\
\hline 6 & G21 & $40 / 1,25 / \mathrm{ms}$ & $40 / 1,25 / \mathrm{ms}$ & $20 / 0,25 / \mathrm{cs}$ & poor \\
\hline 7 & RM0101S5 & $40 / 1,25 / \mathrm{ms}$ & $40 / 1,25 / \mathrm{ms}$ & $20 / 0,25 / \mathrm{cs}$ & poor \\
\hline 9 & RM0101S1 & $50 / 1,75 / \mathrm{ms}$ & $40 / 1,25 / \mathrm{ms}$ & $20 / 0,25 / \mathrm{cs}$ & poor \\
\hline 10 & RM0101S2 & $50 / 1,75 / \mathrm{ms}$ & $50 / 1,75 / \mathrm{ms}$ & $40 / 1,25 / \mathrm{ms}$ & very poor \\
\hline 11 & M37 & $70 / 2,25 / \mathrm{fs}$ & $70 / 2,25 / \mathrm{fs}$ & $40 / 1,25 / \mathrm{ms}$ & very poor \\
\hline 12 & M35 & $70 / 2,25 / \mathrm{fs}$ & $70 / 2,25 /$ fs & $30 / 0,75 / \mathrm{cs}$ & very poor \\
\hline 13 & M33 & $70 / 2,25 / \mathrm{fs}$ & $50 / 1,75 / \mathrm{ms}$ & $30 / 0,75 / \mathrm{cs}$ & very poor \\
\hline \multicolumn{6}{|c|}{ Explanation } \\
\hline \multicolumn{6}{|c|}{ Reading on the sample: } \\
\hline \multicolumn{6}{|c|}{ Mesh size 30 / diameter: $0.75 \mathrm{~mm} /$ grain size (Cs): Coarse sand } \\
\hline
\end{tabular}

The grainsize distribution of rock samples in the study area are dominated by multimodal and bimodal pattern. The samples from the Cirompoki River and Kadu River show multimodal pattern (Figure 7 and Figure 8), while the samples taken from the Cimaningtim River exhibit bimodal patterns (Figure 9). This case occurs due to the difference in the settling current system at different depth of depositional environments.

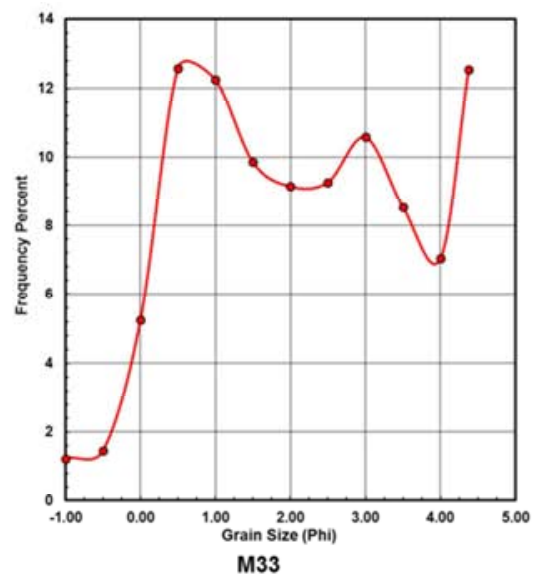

According to cumulative curve of grainsize distribution of the samples can be seen that sample from Cirompoki River dominated by saltation and suspension process Figure 10), the sample from Kadu River showed a balance of saltation and suspension process (Figure 11) and the sample from Cimaningtim River seen again a dominance of saltation and suspension process with addition of traction currents (Figure 12).


Figure 7. Grainsize curve of from Cirompoki River Samples. 

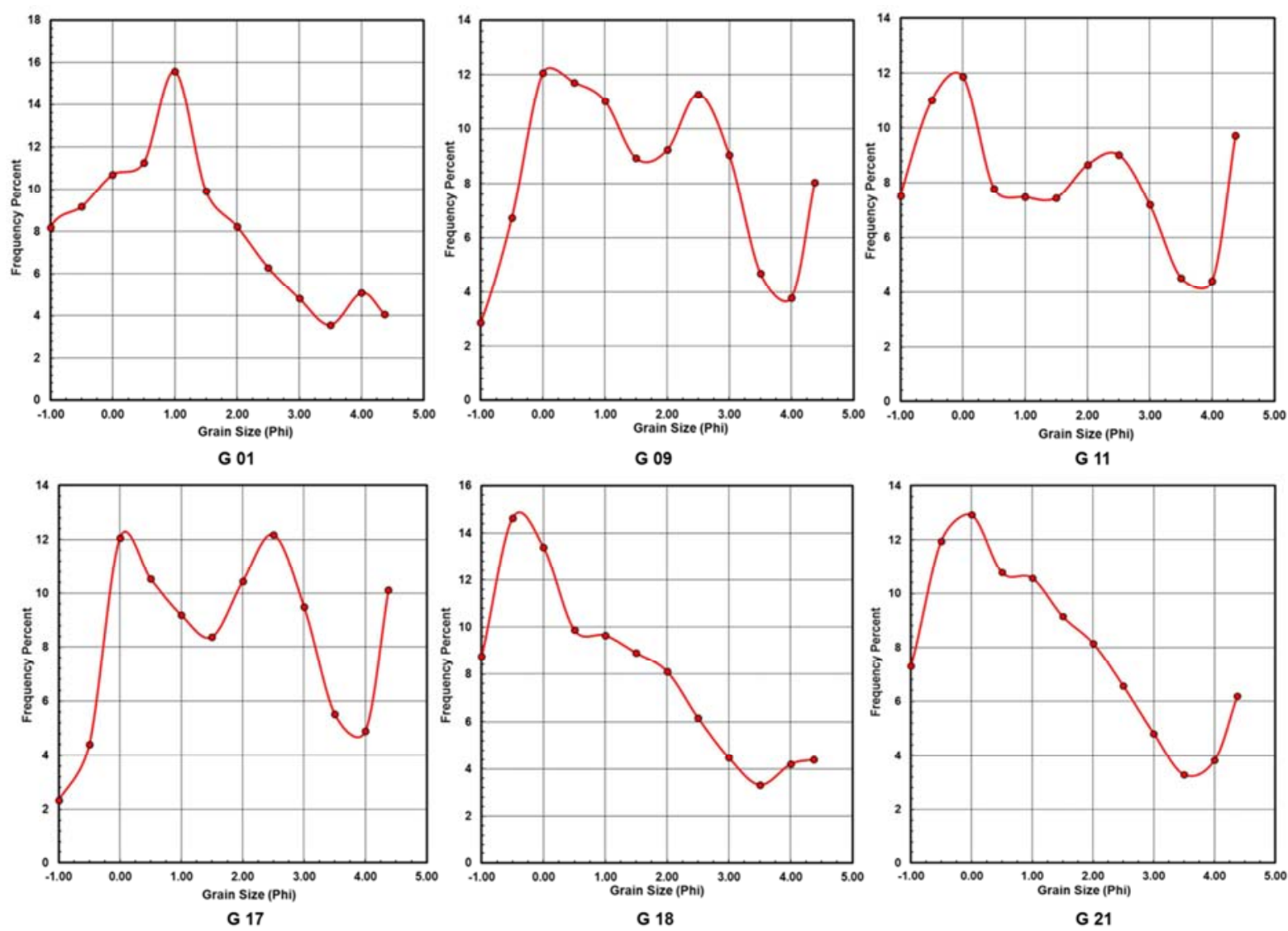

Figure 8. Grainsize curve of from Kadu River Sample.
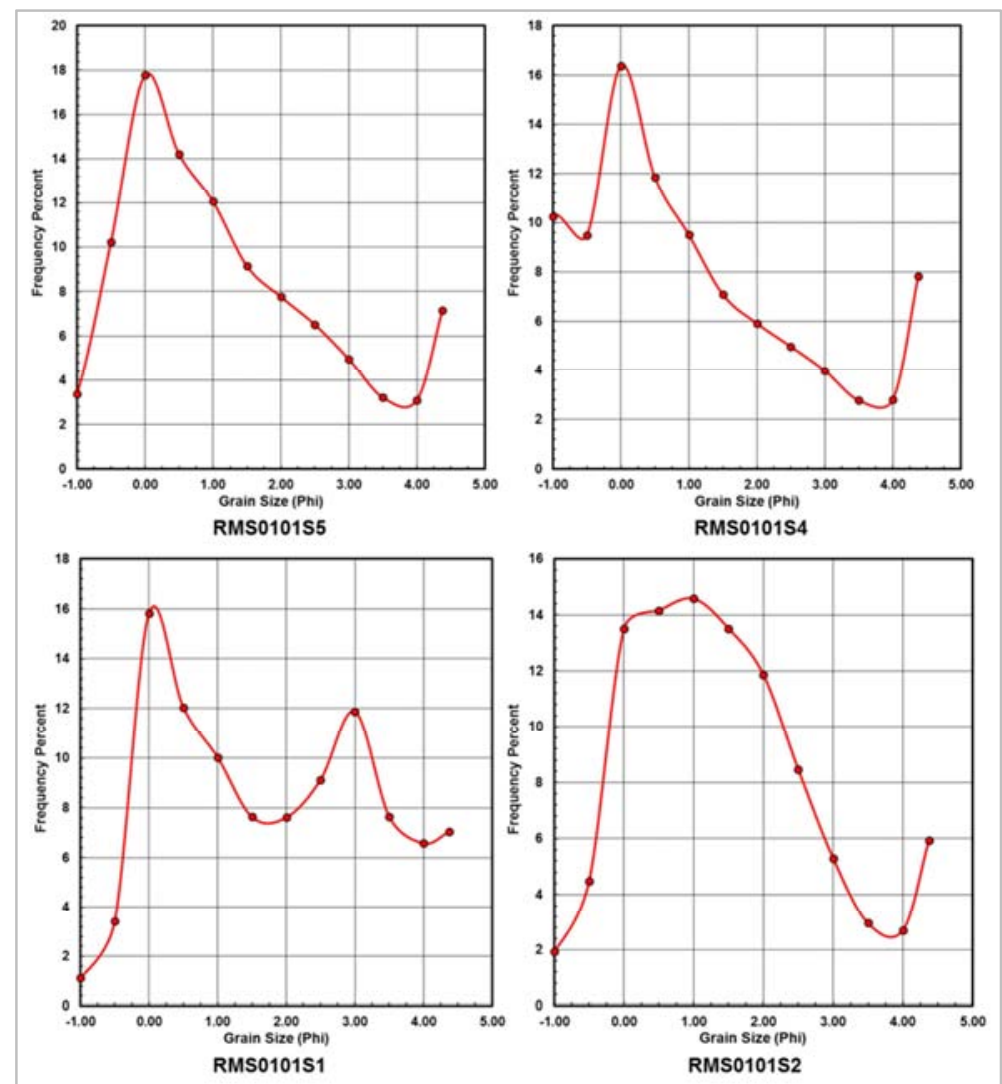

Figure 9. Grainsize curve of from Cimaningtim River Samples. 
Histogram Graph

Cumulative Graph

M37

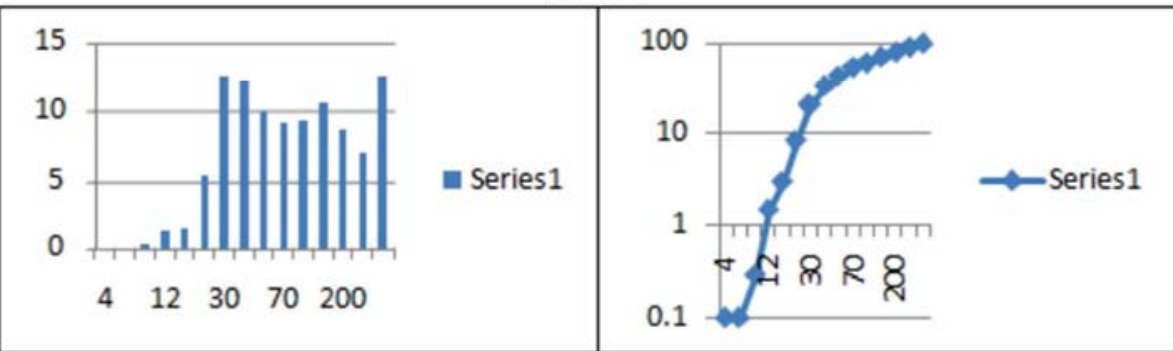

M35



M33

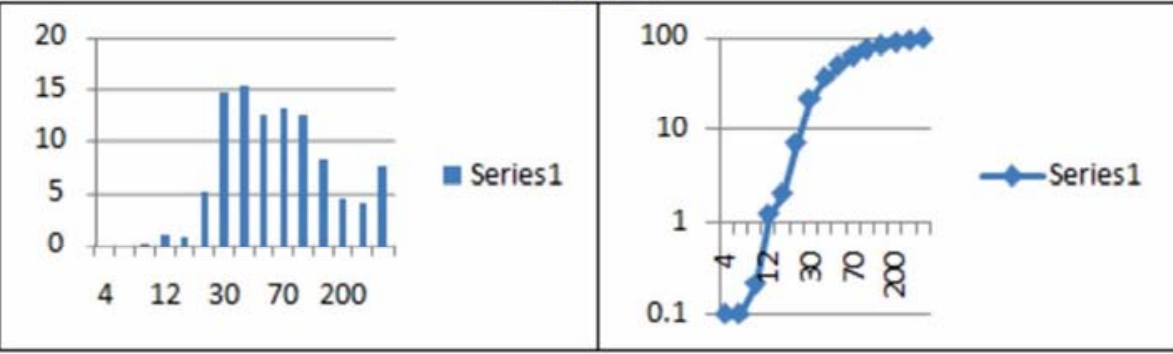

Figure 10. Grainsize distribution of the sample from Cirompoki River.

Histogram Graph Cumulative Graph Histogram Graph Cumulative Graph

RM0105S1

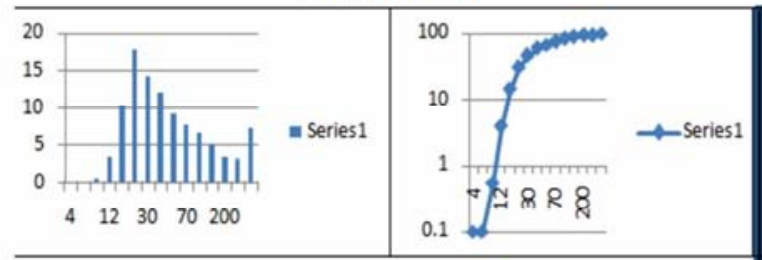

RM0102S1



Figure 11. Grainsize distribution of the sample from Kadu River. 


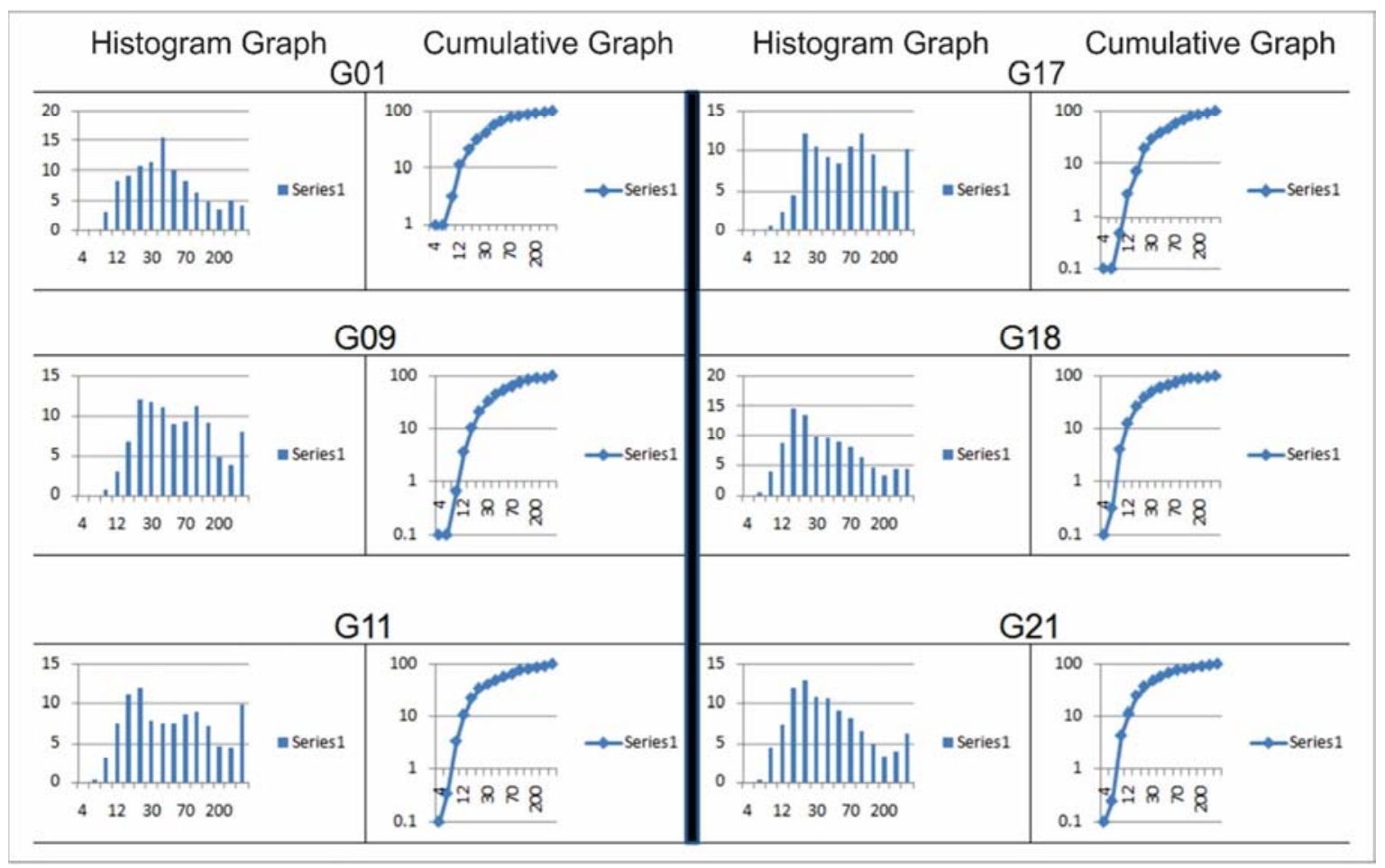

Figure 12. Grainsize distribution of the sample from Cimaningtim River.

\section{Discussion}

\subsection{Integration Analysis}

Based on the results of granulometry analysis, histogram graph from rock samples (old to young) showed a change in grainsize mean value. In the oldest part represented by samples of M33, M35 and M37 from Cirompoki River, the average size of the grain is at a diameter of 149 microns (mesh 100) or proportional to the size of fine sand, which has very low energy starting to strengthen in the middle to top which is represented by samples from Kadu River and Cimaningtim River. This energy is interpreted as the flow of sediment transport carriers.

The middle part is represented by RM0101S2, RM01001S1, RM01001S4 and RM01001S5 sample, the average size of the grain is at 297 microns (mesh 50) or in proportion to the size of medium sand. And at the top represented by the G21 sample, G18, G17, G11, G09, and G01 have average grain size at 420 diameter (mesh 40) or equal to medium sand. This is more clearly shown in Figure 13.
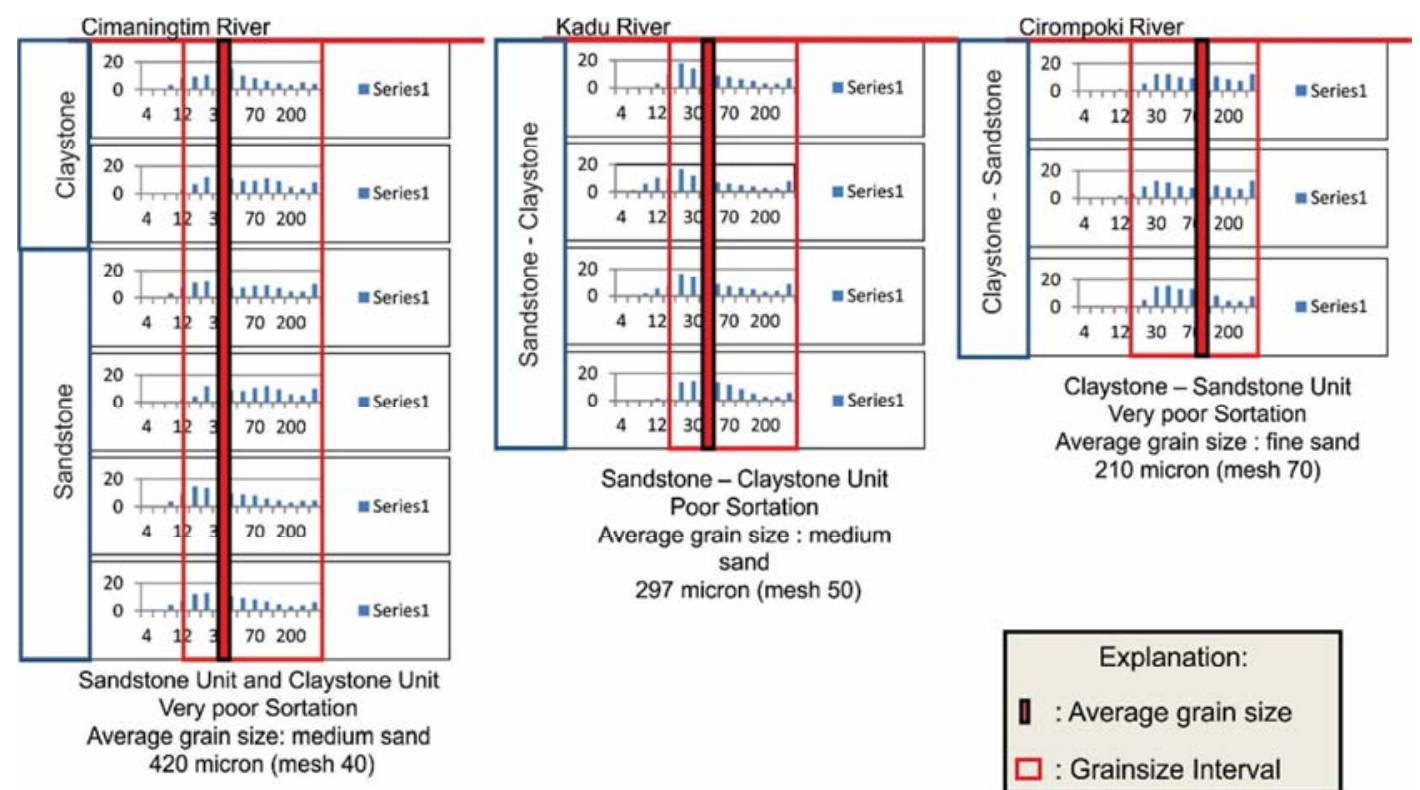

Figure 13. An Average grainize and sorting distribution of the sandstone samples of Cinambo Formation. 
In the Cirompok River (samples M33, M35 and M37), all cumulative graphs are in the finer grain population. This graph shows the mechanism of suspension current $(63 \%)$ and saltation (37\%). The sample lines of M33 and M35 indicate a fracture or separation in the middle, which is interpreted as a current reversal that occurs due to the density of the turbidity of the moving period against the density of water in the deep ocean. When there is a current reversal, the grains are mixed in turbulent conditions so that grain sorting becomes poor. In the Kadu River (samples RM0101S2, RM0101S1, RM0101S4 and RM0101S5), the cumulative graph changed to a medium sand grain population. This is the result of the addition of current energy. This graph also shows relatively comparable current mechanisms between saltation (53\%) and suspension (47\%). The straight graph form without any fault shows a steady current. In the Cimaningtim River (samples G21, G18, G17, G11, G09 and G01), the cumulative graph is divided into 2 patterns. The first pattern is the cumulative graph that is in the population of coarse sand grains (G21, G18, G11 and G01), and the second pattern is in the moderate sand garin population (G17 and G09). The first pattern has a suspension current mechanism $(45 \%)$, saltation $(50 \%)$ and traction $(5 \%)$. While the second pattern has a suspension current mechanism (50\%) of saltation $(50 \%)$. Changes in current mechanisms occurring from beginning to ending are divided by the rocks sampling data group of, as shown in the cumulative graph in Figure 14.
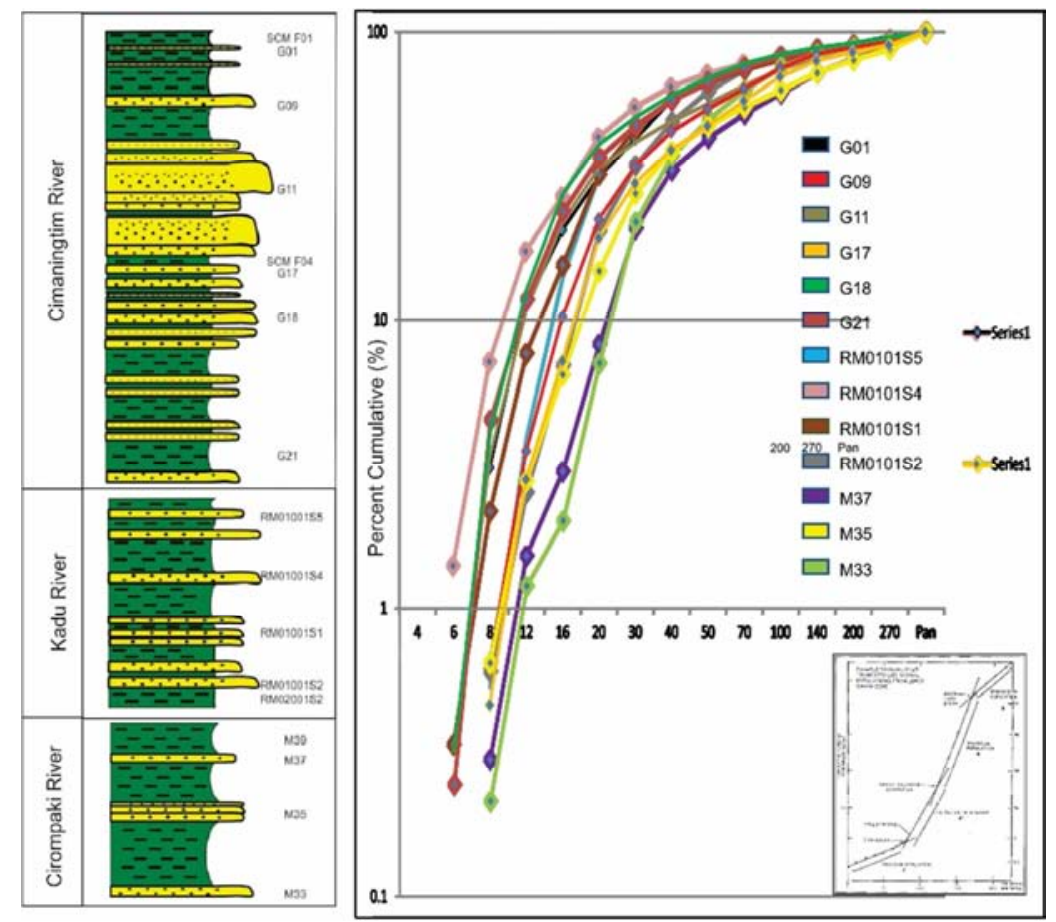

Figure 14. Unification of cumulative grainsize charts from Cinambo Formations sand samples.

The presence of a coarsening sediment grainize with a saltation current mechanism, suspension and slight traction, interpreted as a change of energy into a greater one. While, the difference in traction current in the first and second patterns interpreted as morphological changes of adjacent environments and which occurs on a short period of time

The combination of granulometric analysis with sediment profiles illustrates that the relationship of lithofacies character change to grain size and current mechanisms that form it are interrelated. At the beginning of sedimentation, the formation of Claystone-sandstone unit with average grain size is fine sand with the dominant suspension sedimentation mechanism which means the current energy is still low. Subsequently formed a unit of Sandstone- claystone unit consist of dominantly medium sand grain size with a balanced deposition current mechanism between saltation and suspension, which means the deposition current increases. And at the time of the formation of Sandstone and
Claystone units with average grain sizes of medium to coarse sand deposited with saltation and suspension currents mekasnisme, and the addition of traction currents indicate that the deposition energy is increasing.

Increased energy during deposition of Cinambo Formation is interpreted as a result of changes in sea level conditions. The Global Eustation Model [10] shown that at the Middle Miocene age there are a relative phase of sea level drops. In this phase there are fluctuations reflecting the rise and fall of sea level that can be caused by changes in wave conditions, tidal, local basin subsidence.

The results of the analysis that compared the tentative model of the current deposition energy with the global eustation model show the similarity of the indentation pattern between samples positions at Ta of Bouma Sequence interval with lower sea level [3]. Based on this it can be concluded that, sediment grains will be carried and deposited with the structure of the gradual changes of the bedding at a time 
when the sea level is relatively drop (Figure 15). This change in deposition current is reflected in the benthic fossil content of the biostratigraphic analysis. At the beginning of the deposition, where current energy is still low in the units of Clay-sandstone still found fossil Gyroidina sp., and in units of Sandstone-claystone found Uvigerina sp. both of which are as guide fossil for upper bathyal environment. The relatively low sedimentation current energy allows these fossils to live and thrive in their sedimentary layers. While in
Sandstone and Claystone unit was not found fossil benthic as initial of upper bathyal environment. So it can be concluded that with the increase of current energy, the sediment grain size also increased. It become coarser, and this made the benthic fossil able no more to live and to thrive in such bathyal environment the sediment grain size also increased. It become coarser, and this made the benthic fossil able no more to live and to thrive in such bathyal environment.

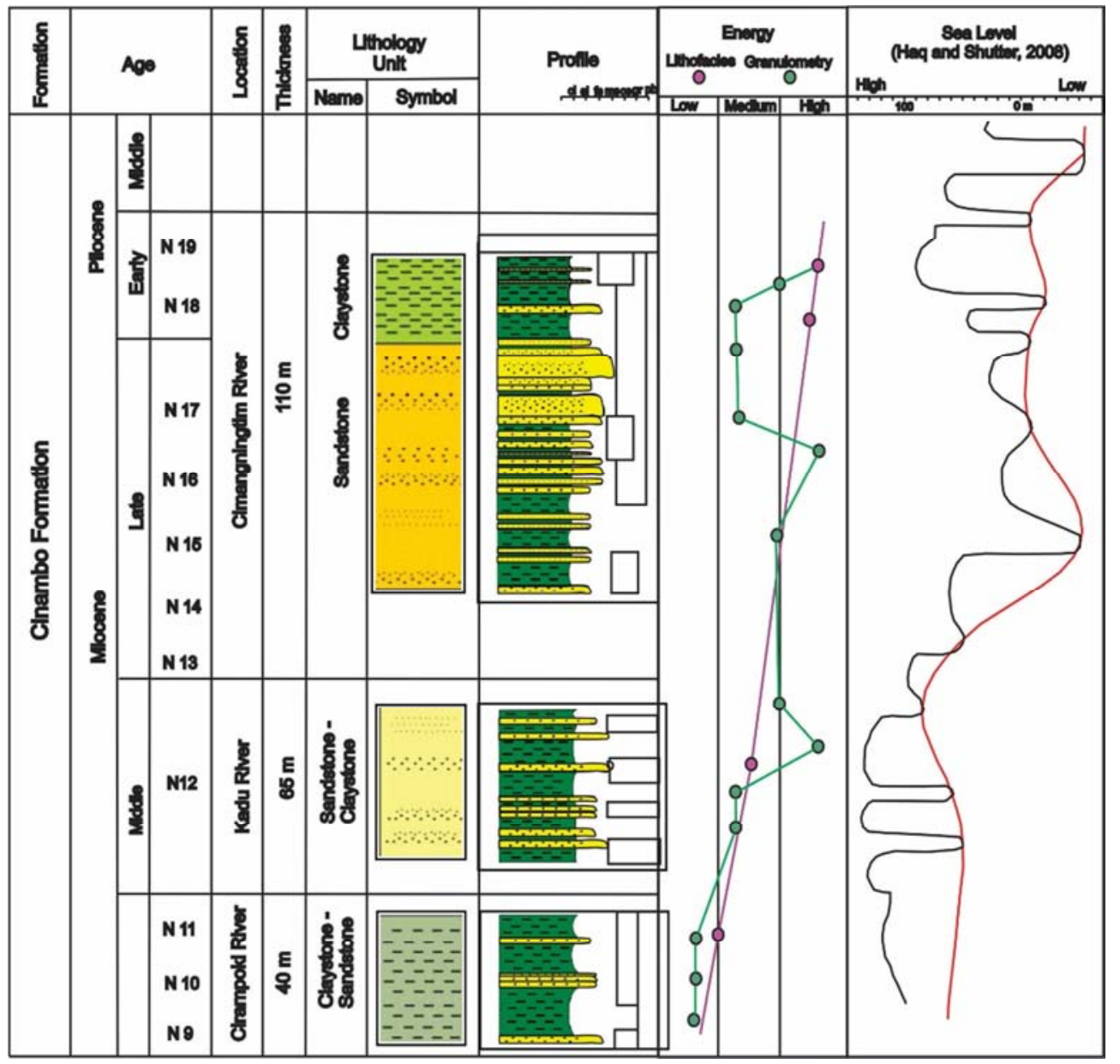

Figure 15. Relation of deposition current energy of Cinambo Formation in research area to global sea level change [10].

Based on the above explanation, combining sediment profile, granulometry and biostratigraphy profiles can be used as a method to determine the possibility of sedimentation conditions in more detail, especially for turbidite deposits within local research boundaries.

\subsection{History of Deposition of Cinambo Formation}

The result of sediment profile analysis, biostratigraphy and granulometry have mutually supportive relationship, that there is change of lithology with different grain size because of different sedimentation current mechanism. This current mechanism changes with the energy of deposition current from low to high energy during the sedimentation period of the Cinambo Formation.

At the deposition of the Cinambo Formation at Middle
Miocene Age, where the current energy is still low deposited the Claystone - sandstone unit (at the Cirompoki River traverse) and the Sandstone - claystone unit (at the Kadu River traverse). This unit is one part of deposition which dominated by thick and massive claystone and to the upper part the presence of sandstone layers increased and the thickness is comparable to the thickness of the claystone. This is a feature of outer part or distal part of deep marine fan environmental. Furthermore, with the increase of current energy at the age of the Late Miocene - the early Pliocene, the grain size of sediment more coarser and changed into sandstone unit and unit of Claystone (on the Cimaningtim River traverse) which deposited in middle part or proximal part of deep marine fan environment. The sandstone unit is part of the channel composed of coarser and thicker sandstones. Above it is constantly deposited the Claystone 
unit which is the result of sedimentation in the inter channel. This unit is composed of dominant claystone and an incessant sandstone layer. The sketch of sedimentation process of Cinambo Formation with its mechanism is shown in Figure 16.

\section{Middle Miocene (N11 - N12)}
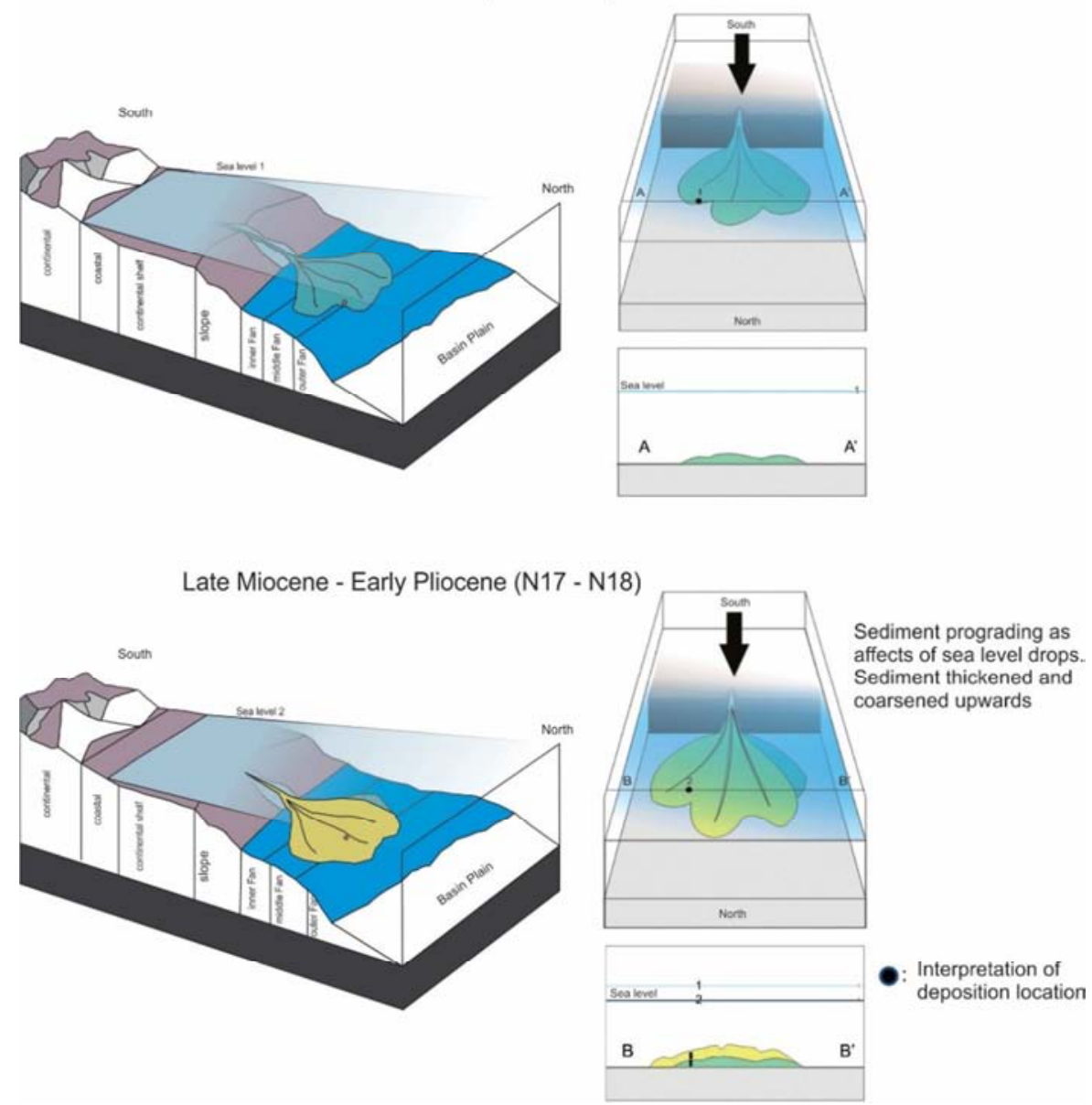

Figure 16. 3D sketch interpretation of the sedimentation mechanism of the Cinambo Formation.

The changing environment of the Cinambo Formation deposition from the outer fan to the middle fan is interpreted as a result of the effect of the decrease of the sea level, under the conditions of the Low Stand Sytem Tract, so that the sedimentation becomes progressively direction of the basin.

\section{Conclusion}

Based on the results of research that has been done, it can be concluded as follows:

The age of Cinambo Formation in the study area is Middle Miocene to Early Pliocene (N11-N18) deposited in the upper bathyal environment as deep marine fan system with the sequence from old to young is Claystone - sandstone unit (at Cirompoki River), Sandstone - claystone unit (at Kadu River), Sandstone unit and Claystone unit (at CimaningtimRiver). The fan system it self change gradually from outer fan to middle fan, which is influenced by the relatively drop of sea level, so that the sediment supply from land becomes prograded toward the basin.

The change of deposition milleu in fan system is interpreted base on granulometric analysis, which shows that the current mechanism of the Claystone - Sandstone Unit is predominant of the suspension, with fine grain size in average and moderate to poor sorting which present mostly as sedimentation in outer fan, the Sandstone-claystone unit is suspension and saltation, medium grain size, poor sorting which present as sedimentation in transition outer to middle fan, and Sandstone Units are dominant saltations with less traction, average grain size is medium sand to coarse sand, very poor sorting as product of sedimentation in middle fan, and the mechanisms of the Claystone Units are suspension and supplements as well as slight traction, average grain size of medium to coarse sand with poor sorting.

\section{References}

[1] Martodjojo, S. (1984) Evolusi Cekungan Bogor, Jawa Barat. Disertasi Doktor, ITB, Bandung.

[2] Djuri (1973) Peta Geologi Lembar Arjawinangun, Skala 1:100.000, Pusat Penelitian dan Pengembangan Geologi.

[3] Bouma, A. H. (2000) Fine-grained, mud-rich turbidite systems: Model and comparison with coarse-grained, sandrich systems: Fine-Grained Turbidite Systems, 68, pp. 9-20. 
[4] Purnamaningsih (1973) Geologi Daerah Cadasngampar Lembar 42 Kabupaten Sumedang Jawa Barat, Skripsi Utama, Universitas Padjajaran Bandung, unpublish.

[5] Clark, J. D., and Pickering, K. T. (1996) Architectural Elements and Growth Patterns of Submarine Channels: Application to Hydrocarbon Exploration. AAPG Bulletin, 80, No. 2, 194-221.

[6] Blow, W. H. (1969) Late Middle Miocene to Recent Planktonic Foraminifera Biostratigraphy, International Conf. Planktonic Microfossils, $1^{\text {st }}$ ed., Geneva (1967), Proc., Leiden, E. Jbrill, vol. 1.

[7] Postuma, J. A. (1971) Manual of Planktonic Foraminifera. Elsevier Science \& Technology, Oxford, United Kingdom.
[8] Stow, D. A. V. (1985) Deep-sea clastics: where are we and where are we going?; in P. J. Brenchley and B. P. J. Williams, eds., Sedimentology: recent developments and applied aspects; Geological Society of London Special Publication 18, Blackwell Scientific Publications, Oxford, 67-93.

[9] Mutti, E. and Lucchi, F. R. (1972) Turbidites of the northern Apennines: Introduction to facies analysis (English translation by T. H. Nilson, 1978): International Geology Review, v. 20, p. 125-166.

[10] Haq, B U. and Schutter, S. R. (2008) A Chronology of Paleozoic sea-level changes. Published in Science. doi: 10.1126/science. 1161648 . 